\title{
Carbonate system distribution south of the Canary Islands in spring 2000
}

\author{
IVÁN R. UCHA ${ }^{1}$, MELCHOR GONZÁLEZ-DÁVILA ${ }^{1}$, \\ MAGDALENA SANTANA-CASIANO ${ }^{1}$, MARÍA JOSÉ RUEDA ${ }^{2}$ and OCTAVIO LLINÁS ${ }^{2}$ \\ ${ }^{1}$ Departamento de Química, Universidad de Las Palmas de Gran Canaria, Campus de Tafira, Las Palmas 35017, Spain. \\ E-mail: mgonzalez@dqui.ulpgc.es \\ ${ }^{2}$ Instituto Canario de Ciencias Marinas, Gobierno de Canarias, Las Palmas de Gran Canaria, Spain.
}

\begin{abstract}
SUMMARY: The measurement of the surface molar fraction of $\mathrm{CO}_{2}$ (atmosphere and sea water) and water column $\mathrm{pH}_{\mathrm{T}}$, total alkalinity, $\mathrm{A}_{\mathrm{T}}$, nutrients and oxygen were carried out in spring 2000 at the European Station for Time Series in the Ocean at the Canary Islands (ESTOC) and in the area located south of the Canary Islands. The significant eddy field strongly affecting the pattern of the chemical and carbonate system variables is presented and discussed. A mixing model based on the thermohaline properties of the water masses was established. The model explained over $97 \%$ of the variability found in the distribution of the chemical variables. Intermediate waters to the south of the Canary Islands show a high contribution of Antarctic waters with about 5\% of pure Antarctic Intermediate Water. Moreover, the surface structure affected the atmosphere-ocean carbon dioxide exchange, making the area act as a $\mathrm{CO}_{2}$ sink taking up $9.1 \mathrm{mmol} \mathrm{m}^{-2}$ week $^{-1}$, corresponding to $0.03 \mathrm{Mt}$ of $\mathrm{CO}_{2}$ which were taken up by the area in a week at the end of March 2000 .
\end{abstract}

Keywords: carbonate chemistry, water masses, eddies, nutrients, oxygen, Canary Islands.

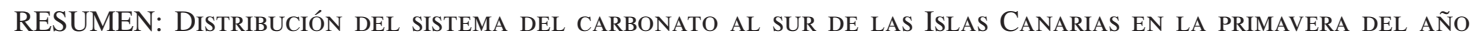
2000. - Durante la primavera del año 2000 se realizaron medidas en las aguas superficiales de la fracción molar de $\mathrm{CO}_{2}$ (atmósfera y océano) y en la columna de agua de $\mathrm{pH}_{\mathrm{T}}$, alcalinidad total, $\mathrm{A}_{\mathrm{T}}$, nutrientes y oxígeno, para la Estación Europea Oceánica de Series Temporales de Canarias (ESTOC) y al sur de las islas Canarias. En este trabajo se presenta y discute el efecto del importante campo de remolinos presente en el área sobre la distribución de las variables químicas y del sistema de carbonato. Se ha establecido un modelo de mezcla, basado en las propiedades termohalinas de las diferentes masas de agua, que explica el 97\% de la variabilidad encontrada en la distribución de las variables químicas. Las aguas intermedias al sur de las islas Canarias están caracterizadas por la alta contribución del agua Antártica intermedia diluida, que corresponde con una contribución próxima al $5 \%$ de agua Antártica intermedia pura. Por otro lado, las estructuras superficiales afectan al intercambio de $\mathrm{CO}_{2}$ atmósfera-océano, actuando el área como un sumidero de dióxido de carbono incorporando $9.1 \mathrm{mmol}$ $\mathrm{m}^{-2}$ semana $^{-1}$, que se corresponde con 0.03 MTon de $\mathrm{CO}_{2}$ captadas por el área y en una semana a finales de marzo del 2000.

Palabras clave: química del carbonato, masas de agua, remolinos, nutrientes, oxígeno, Islas Canarias.

\section{INTRODUCTION}

The oceans have been divided into domains and provinces according to their ecological and physical features (Longhurst, 1998). The Canary Islands region is located in the westerly domain corresponding to the North Atlantic Subtropical Gyre province (NASE). This region is a transitional zone between the northwestern African coastal upwelling region and the open ocean oligotrophic waters of the subtropical gyre. It is well known that the eastward flowing of the Azores Current splits into several southward branches (Reid, 1994). The branch which always flows eastward into the coastal upwelling region off northwest Africa is identified as the Canary Current. The islands present a barrier to this relatively weak equatorward flow of the Canary Current and to the flow of the trade winds due to the abrupt topography of the islands, which leads 
to a variety of mesoscale phenomena south of the islands. These include a significant downstream wake (Arístegui et al., 1994, 1997; Barton et al., 1998; Davenport et al., 1999) that has a great effect on the biogeochemical cycles of the region (González-Dávila et al., 2003, 2006). Barton and Arístegui (2004) studied the changing properties of waters as they are advected towards the open ocean in filaments. They also investigated the exchange between filaments and eddies that re-circulated water parcels for several weeks.

Many researchers have studied the role of eddies that transport nutrients, taking the upwelled waters through the filaments to the oligotrophic area, including the Canary islands region (Falkowski et al., 1991; McGillicuddy et al., 2003; Arístegui et al., 2004; Barton et al., 2000; Barton and Arístegui, 2004) and the different upwelling cells (Cape Ghir, Cape Juby and Cape Bojador). Little work has been done on the effects of variability on the carbonate system. Most of the $\mathrm{CO}_{2}$ work has been carried out in the northern part of the Canary Islands (Santana-Casiano et al., 2001, 2007; Pérez et al., 2001; González-Dávila et al., 2003, 2007), where there is no island effect. Only GonzálezDávila et al. (2006) studied the effect of cyclonic and anticyclonic eddies on the nutrient pumping and on the upward displacement of dissolved inorganic carbon, observed from the northwest to the south central area of the Canary Islands. They also applied a model to determine the net inorganic carbon balance in a cyclonic eddy.
During the Poseidon 257 cruise, the area to the south of the Canary Islands was sampled in March 2000 as a hydrographic line crossing the multiple mesoscale features including cyclonic and anticyclonic gyres, filaments and wakes that affect the water mass transport and associated biogeochemical fluxes. The eastern North Atlantic area to the south of the Canary Islands (Fig. 1) is characterized by the presence of different water masses with thermohaline properties extensively described in the literature. In the upper waters two varieties of Eastern North Atlantic Central Water (ENACW), subtropical (tENACW) and subpolar (pENACW) (Harvey, 1982; Ríos et al., 1992; Pollard et al., 1996), have been defined at different isopycnal levels. The intermediate waters encountered to the south of the islands are influenced by the presence of diluted Antarctic Intermediate Water (AA) (Machín and Pelegrí, 2009) characterized by an oxygen-minimum and nutrient maximum domain, affecting intermediate water approximately to $20^{\circ} \mathrm{N}$ (Speer, 1993, Reid 1994). The influence of Mediterranean water (MW) can be found in the Canary Islands from 900 down to $1800 \mathrm{~m}$ (Reid, 1994, Santana-Casiano et al., 2001). The deep waters are dominated by the Northeast Atlantic Deep Water (NEADW) detected by the small variability and linearity in the thermohaline structure, which is divided into upper North Atlantic Deep Water (uNEADW) and lower Northeast Atlantic Deep Water (INEADW) (Wright and Worthington, 1970).

The present study focused on the carbonate system to the south of the Canary Islands and the effect of the

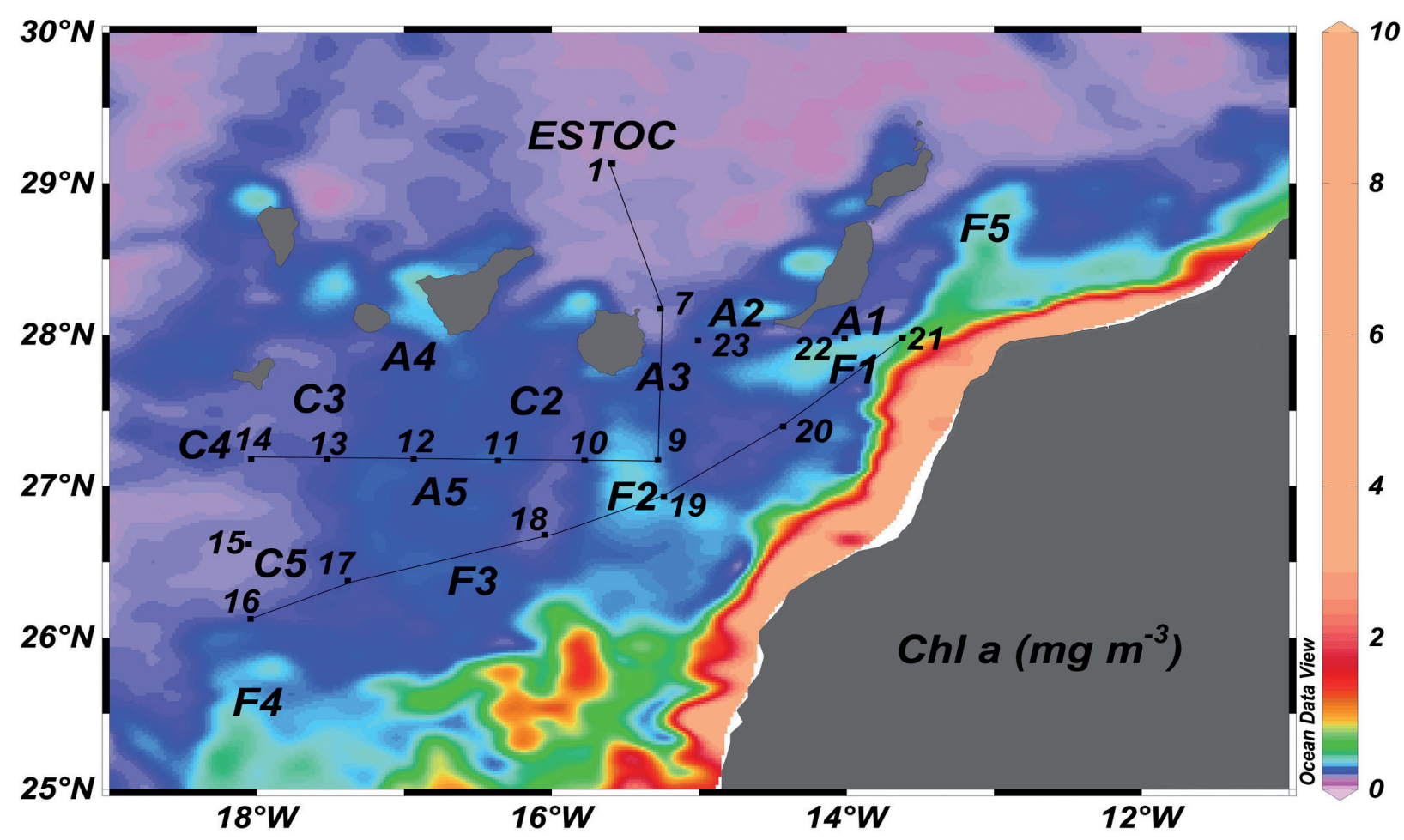

FIG. 1. - Satellite image from 19 March 2000 for the study area showing an important mesoscale structure south of the Canary Islands. Cyclonic (C) and anticyclone (A) eddy and filament (F) locations discussed in the text are labelled, as is the position of ESTOC site. 
mesoscale structure on its variability. We used a mixing model based on the water masses present in the area, considering a set of vertically ordered mixing triangles to study the chemical variability of the water masses (Tomczak, 1981; Pérez et al., 2001). A single and fixed temperature and salinity defined each water mass end-member in a triangle while a water mass showed a fixed TS relationship characterized by a mixing of two end-members. In order to improve our knowledge of the $\mathrm{CO}_{2}$ system, the anthropogenic carbon fraction was studied using the TrOCA method (Touratier et al., 2007). Special attention was paid to the spreading of $\mathrm{AA}$ in the area.

\section{MATERIALS AND METHODS}

pH

The $\mathrm{pH}$ in total scale (moles $(\mathrm{kg} \mathrm{sw})^{-1}$ ) was measured following the spectrophotometric technique of Clayton and Byrne (1993) using the m-cresol purple indicator (DOE, 1994). The $\mathrm{pH}$ measurements were done with a system described in detail in GonzálezDávila et al. (2003). Repeated seawater measurements of different CRMs samples $(n=54)$ give a weighted standard deviation of $\pm 0.002 \mathrm{pH}$ units.

\section{Total alkalinity}

Total alkalinity of seawater $\left(\mathrm{A}_{\mathrm{T}}\right)$ was determined by titration with $\mathrm{HCl}$ until the carbonic acid end point using two similar potentiometric systems, as indicated in Mintrop et al. (2000). The precision of the fit (s value)

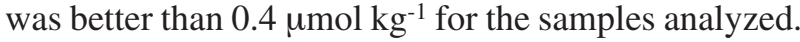
The performance of the titration systems $( \pm 1.5 \mu \mathrm{mol}$ $\mathrm{kg}^{-1}$ ) was monitored by titrating different samples of certify reference material CRMs (\#42) that have known $\mathrm{C}_{\mathrm{T}}$ and $\mathrm{A}_{\mathrm{T}}$. Total alkalinity normalized to a constant salinity of 35 was computed where necessary $\left(\mathrm{NA}_{\mathrm{T}}=\right.$ $\left.\mathrm{A}_{\mathrm{T}} / \mathrm{S} \cdot 35\right)$.

\section{Total dissolved inorganic carbon}

Total inorganic carbon $\left(\mathrm{C}_{\mathrm{T}}\right)$ was computed from experimental values of $\mathrm{pH}_{\mathrm{T}}$ and $\mathrm{A}_{\mathrm{T}}$, using the carbonic acid dissociation constants of Mehrbach et al. (1973) according to Dickson and Millero (1987). This set of constants showed the greatest agreement between $\mathrm{C}_{\mathrm{T}}$ $\left(\mathrm{pH}, \mathrm{A}_{\mathrm{T}}\right)$ calculations and certified $\mathrm{C}_{\mathrm{T}}$ values for CRM, batch 42 , with a $C_{T}$ residual of $\pm 3 \mu \mathrm{mol} \mathrm{kg} \mathrm{kg}^{-1}(\mathrm{n}=54)$. Total inorganic carbon normalized to a constant salinity of 35 was computed where necessary $(\mathrm{NCT}=\mathrm{CT}$ /S · 35).

Partial pressure of $\mathrm{CO}_{2}$ expressed as fugacity, $\mathrm{fCO}_{2}$. $\mathrm{CO}_{2}$ flux determination.

Fugacity of carbon dioxide $\left(\mathrm{CO}_{2}\right)$ in air and in surface seawater is determined with a flowing sys- tem similar to the one designed by Wanninkhof and Thoning (1993), developed by Frank J. Millero's group at the University of Miami and described in detail in González-Dávila et al. (2003). The system was calibrated by measuring three different standard gases with mixing ratios of $0.0,348.55$ and 520.83 ppm $\mathrm{CO}_{2}$ in air. Our system has a precision of less than $1 \mu$ atm and is accurate, relative to the standard gases, to $2 \mu \mathrm{atm}$. Fugacity of $\mathrm{CO}_{2}$ in the seawater was calculated from the measured $\mathrm{xCO}_{2}$ (mole fraction of $\mathrm{CO}_{2}$ gas corrected to dry air and to the pressure of $1 \mathrm{~atm})$.

The fluxes of $\mathrm{CO}_{2}$ were calculated by

$$
F \mathrm{CO}_{2}=K\left(f \mathrm{CO}_{2, s w}-f \mathrm{CO}_{2, a t m}\right)
$$

The $\mathrm{CO}_{2}$ exchange coefficient $K$, in mol m-2 $\mathrm{yr}^{-1}$ uatm $^{-1}$ was deduced as:

$$
K=k \times S / 11.1371
$$

where $k$ in $\mathrm{cm} \mathrm{h}^{-1}$ is the transfer velocity coefficient and $\mathrm{S}$ is the solubility in mol kg-1 $\mathrm{atm}^{-1}$ deduced from SST using polynomial coefficients after Wanninkhof (1992). 11.1371 is a conversion factor computed assuming seawater density of $1025 \mathrm{~kg} \mathrm{~m}^{-3} . k$ is deduced from satellite wind speeds at $10 \mathrm{~m}$ height, $\mathrm{U}_{10}$, and SST using Wanninkhof (1992) k-U ${ }_{10}$ parameterization:

$$
k_{w}=\left(0.31 U_{10}^{2}\right) \times \sqrt{\left(660 / S_{C}\right)}
$$

Wind speed was retrieved at a $25 \mathrm{~km}$ resolution from instantaneous $25 \mathrm{~km}$ scatterometer measurement, as indicated by Boutin and Echeto (1995), and was provided by LOCEAN, University Pierre et Marie Curie, http://www.locean-ipsl.upmc.fr. Gas solubility and Schmidt number, Sc, are computed for a constant salinity of 35 and for a sea surface temperature, SST, averaged over $1^{\circ}$ and 1 month. The SST fields are the ones generated at the French National Meteorological Centre (NMC) by an optimal interpolation of AVHRR and in situ data (Reynolds and Smith, 1994).

\section{Nutrients, chlorophyll $a$ and oxygen}

Samples for nutrients, chlorophyll $a$ and oxygen were analyzed in the lab following the World Ocean Circulation Experiments (WOCE) standards (WOCE, 1994). For silicates, a modified Hansen and Grasshoff (1983) method was used, in which $\beta$-silicomolybdenic acid is reduced with ascorbic acid. The standard devia-

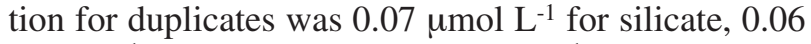
$\mu \mathrm{mol} \mathrm{L}-1$ for nitrate and $0.01 \mu \mathrm{mol} \mathrm{L}-1$ for phosphate. The standard error for five oxygen replicates was less than $2 \mu \mathrm{mol} \mathrm{kg} \mathrm{kg}^{-1}$. The chlorophyll $a$ was measured using fluorometric analysis according to the methodology described by Welschmeyer (1994), using a TURNER ${ }^{\mathrm{TM}}$ 10-AU-000 fluorometer. 


\section{Mixing analysis}

The contribution of the water masses $\mathrm{M}_{\mathrm{k}, \mathrm{i}}$ considered for a given sample $i$ can be calculated using the following linear equations:

$$
\begin{gathered}
1=\sum M_{k, i} \\
S_{i}=\sum M_{k, i} S_{k} \\
\theta=\sum M_{k, i} \theta_{k}
\end{gathered}
$$

where $k$ is the water mass and $i$ is the sample number (from 1 to 368, in our study). $S_{k}$ and $\theta_{k}$ are the thermohaline characteristics of the water mass end-member for each mixing triangle considered. Since the proportion of the water masses has to be calculated for all the samples, a non-negative least squares (NNLS) approach is used. The $M_{k, i}$ proportions for each sample were then applied to compute the expected concentration of any chemical variable for the water masses considered in the area by solving the 368 equations by the same NNLS method.

$$
C_{i}=\sum M_{k, i} C_{k}
$$

In order to know the sensibility of our final result of $C_{k}$ with respect to the initial reference values of $\theta$ and $S$ (after Perez et al., 2001), we studied the error propagation through a Monte Carlo approach (Hammersley and Handscomb, 1964), considering the error in Table 1 in the initial reference variables $\theta$ and $S$ obtained by applying an extended optimum multiparameter analysis (Álvarez et al., 2005) for the eastern North Atlantic. An extensive discussion of this methodology and its validity can be found elsewhere (Castro et al., 1998;
Pérez et al., 1998; 2001); we followed the last recommendation by Pérez et al. (2001) and Álvarez et al. (2005).

\section{RESULTS}

\section{Hydrography}

A grid of 17 stations divided into 3 major lines was measured to the south of the Canary Islands (Fig. 1). Line 1 joined stations located at around $27^{\circ} \mathrm{N}$ (sts. 9 to 14). Line 2 followed stations 16 to station 21 approaching the Africa coast, while line 3 crossed the area north to south from the ESTOC site (st. 1) to station 19 along $15^{\circ} \mathrm{W}$.

\section{Upper thermocline distribution}

SeaWIFS images (Fig. 1) revealed the spectacular scenario of a series of eddies spinning cyclonically (C) and anticyclonically (A) downstream of the islands of the Canary Archipelago. The strong upwelling cells located at Capes Juby and Bojador affected the area due to the generation of filaments reaching the field of eddies and interacting with them. Two filaments (F1 and F2) located near Cape Juby extended offshore and were traced to the southwest of Fuerteventura (F1), while F2 turned southward around the quasi-permanent cyclonic circulation $(\mathrm{C} 1)$ trapped in the trough south of Gran Canaria. At their offshore limit, the anticyclone A3 was partly entrained around the anticyclone shed from the island of Gran Canaria. Another filament (F3) generated at Cape Bojador was observed to the south of Tenerife interacting with cyclonic eddy C5 and anticy-

TABLE 1. - Definition of source water types and their chemical properties (in $\mu \mathrm{mol} \mathrm{kg}^{-1}$ ) obtained from the mixing model using 359 water

\begin{tabular}{|c|c|c|c|c|c|c|}
\hline & $S$ & $\theta$ & $\mathrm{O}_{2}$ & $\mathrm{AOU}$ & $\mathrm{NO}_{3}$ & $\mathrm{SiO}_{2}$ \\
\hline MMW & $37.05 \pm 0.04$ & $20.00 \pm 0.5$ & $231 \pm 6$ & -3 & $0.2 \pm 0.1$ & $0.3 \pm 0.05$ \\
\hline tENACW & $36.15 \pm 0.02$ & $15.35 \pm 0.4$ & $228 \pm 4$ & -1 & $7.2 \pm 0.9$ & $1.8 \pm 0.30$ \\
\hline pENACW & $35.23 \pm 0.01$ & $8.56 \pm 0.3$ & $159 \pm 1$ & 119 & $24.8 \pm 0.6$ & $14.7 \pm 0.6$ \\
\hline AA & $34.9 \pm 0.02$ & $6.5 \pm 0.1$ & $116 \pm 2$ & 184 & $29.3 \pm 0.2$ & $20.3 \pm 0.3$ \\
\hline MW & $36.5 \pm 0.01$ & $11.74 \pm 0.1$ & $201 \pm 8$ & 62 & $13.9 \pm 1.5$ & $7.9 \pm 1.0$ \\
\hline uNEADW & $34.93 \pm 0.00$ & $2.5 \pm 0.1$ & $244 \pm 1$ & 81 & $21.1 \pm 0.1$ & $33.2 \pm 0.1$ \\
\hline $\mathrm{R}^{2}$ & & & 0.961 & & 0.960 & 0.973 \\
\hline \multirow[t]{2}{*}{ SD } & & & 8.36 & & 1.37 & 1.72 \\
\hline & $\mathrm{PO}_{4} \mathrm{H}_{2}$ & $C_{T}$ & $\mathrm{~A}_{\mathrm{T}}$ & $\mathrm{pH}_{\mathrm{T}}$ & $\mathrm{NC}_{\mathrm{T}, \text { bio }}$ & $\mathrm{NC}_{\mathrm{T}, \text { bio }}{ }^{*}$ \\
\hline MMW & $0.01 \pm 0.01$ & $2082 \pm 12$ & $2418 \pm 3$ & $8.058 \pm 0.108$ & $1979 \pm 2$ & 1989a \\
\hline tENACW & $0.43 \pm 0.05$ & $2130 \pm 7$ & $2361 \pm 1$ & $7.894 \pm 0.005$ & $2007 \pm 4$ & $2012 \pm 26$ \\
\hline $\mathrm{H}$ & $0.90 \pm 0.06$ & $2150 \pm 6$ & $2333 \pm 2$ & $7.785 \pm 0.007$ & $2049 \pm 3$ & $2060 \pm 6$ \\
\hline AA & $1.91 \pm 0.03$ & $2221 \pm 1$ & $2312 \pm 1$ & $7.564 \pm 0.004$ & $2092 \pm 1$ & $2093 \pm 4$ \\
\hline MW & $0.71 \pm 0.08$ & $2204 \pm 4$ & $2414 \pm 3$ & $7.827 \pm 0.012$ & $2067 \pm 2$ & $2067 \pm 7$ \\
\hline uNEADW & $1.39 \pm 0.00$ & $2200 \pm 0$ & $2341 \pm 1$ & $7.723 \pm 0.001$ & $2136 \pm 1$ & $2133 \pm 3$ \\
\hline INEADW & $1.59 \pm 0.00$ & $2211 \pm 0$ & $2360 \pm 0$ & $7.722 \pm 0.001$ & $2148 \pm 0$ & $2149 \pm 1$ \\
\hline $\mathrm{R}^{2}$ & 0.963 & 0.961 & 0.972 & 0.983 & 0.973 & \\
\hline SD & 0.10 & 7.62 & 3.82 & 0.012 & 6.82 & \\
\hline
\end{tabular}
samples. Errors in $S$ and $\theta$ after Álvarez et al. (2005).

* Pérez et al., 2001; a Álvarez et al., 2005. 


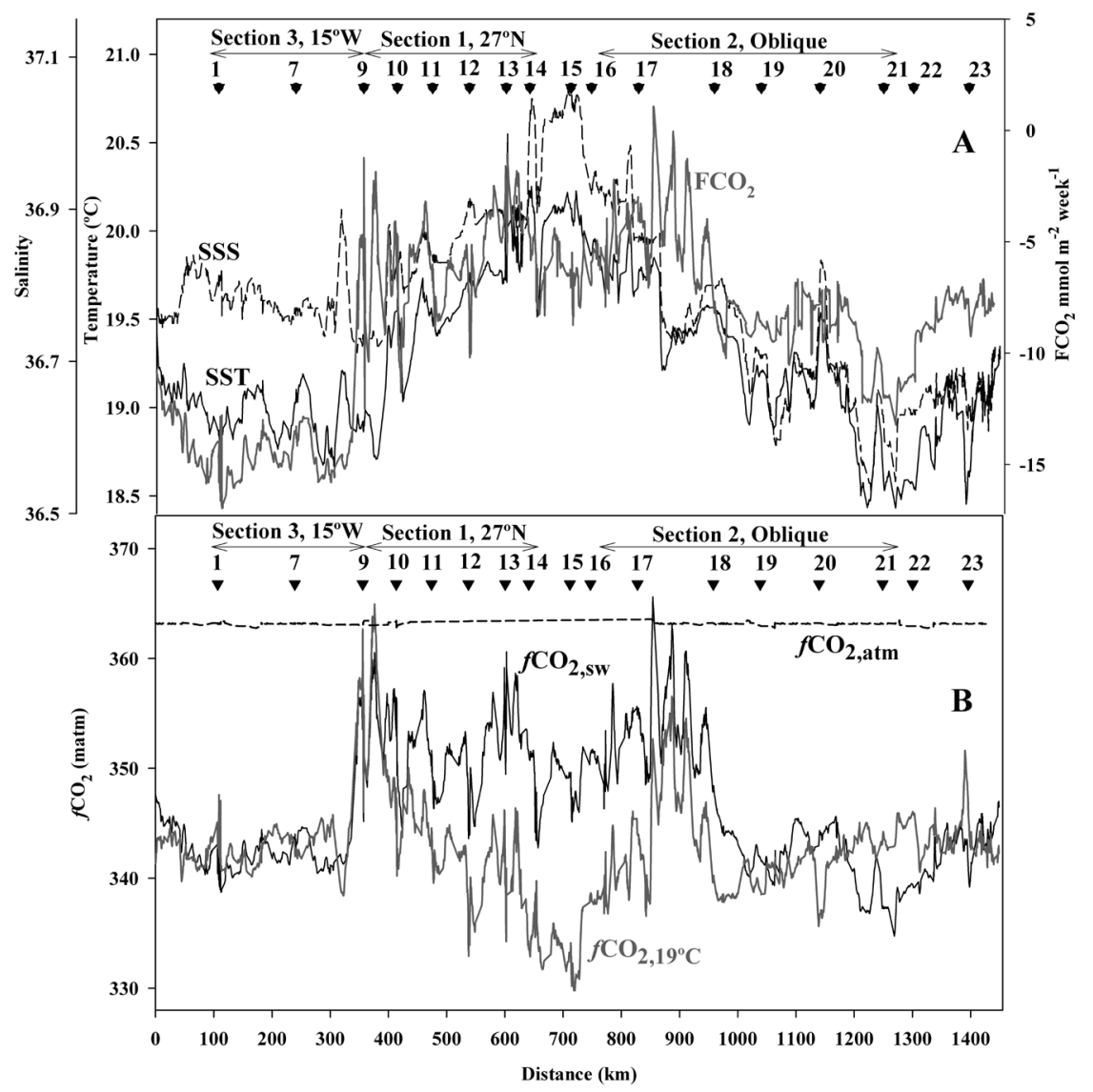

FIG. 2. - Distribution of A) sea surface temperature (SST), salinity (SSS) and $\mathrm{CO}_{2}$ fluxes $\left(\mathrm{FCO}_{2}\right.$ ) using satellite wind speeds. B) $\mathrm{CO}_{2}$ fugacity in the atmosphere $\left(f \mathrm{CO}_{2, \mathrm{~atm}}\right)$, in the ocean $\left(f \mathrm{CO}_{2, \mathrm{sw}}\right)$ and normalized to $19^{\circ} \mathrm{C},\left(f \mathrm{CO}_{2,19^{\circ} \mathrm{C}}\right)$ along the cruise track. The main mesoscale structures are indicated together with the stations.

clone A5. A more complex structure was found south of $26^{\circ} \mathrm{N}$ outside the area studied on this cruise. Line 1 ran westward along $27^{\circ} \mathrm{N}$ between Gran Canaria and the outer island of El Hierro. It started close to the quasi-permanent feature observed south of Gran Canaria, anticyclone A3, but immediately went inside the coupled pair $\mathrm{C} 2$ and F2 and crossed between anticyclones A4 and A5. It moved into the area affected by cyclonic eddy $\mathrm{C} 3$ located east of El Hierro and finished close to cyclone $\mathrm{C} 4$, to the southwest of El Hierro. The oblique line close to the African coastline, line 2, started at the position of anticyclone $\mathrm{A} 6$ at $26^{\circ} \mathrm{N}$, crossed cyclones $\mathrm{C} 5$ and $\mathrm{C} 1$ and intersected the filament generated at Cape Bojador $\mathrm{F} 3$ at around $17^{\circ} \mathrm{W}$ and those generated at Cape Jubi at $15.5^{\circ} \mathrm{W}$ and $15^{\circ} \mathrm{W}$ (F2 and F1) at the end of the line, where anticyclone A1 to the south of the Island of Fuerteventura is located.

Along line 1, the sea surface temperature (SST) (Fig. 2) increased from $18.7^{\circ} \mathrm{C}$ where filament $\mathrm{F} 2$ and cyclone $\mathrm{C} 2$ are located, close to station 10 , to $20.25^{\circ} \mathrm{C}$ before reaching station 14 . At $17.5^{\circ} \mathrm{W}$, cyclone $\mathrm{C} 4$ injected warm surface seawater in the line located west of $18^{\circ} \mathrm{W}$, as can be seen in the SST images for the area (not shown), reaching a temperature of $20.25^{\circ} \mathrm{C}$ and a sea surface salinity (SSS) of 37.05 . At $18^{\circ} \mathrm{W}$, the tem- perature and salinity fell dramatically by $0.75^{\circ} \mathrm{C}$ and 0.18 , respectively, due to the presence of cyclonic eddy C4. Surface properties also showed the effects of filament $\mathrm{F} 2$ at $16^{\circ} \mathrm{W}$ and anticyclones A4-A5 at $16.5^{\circ} \mathrm{W}$. The effect of the eddy field can also be clearly observed in the uplifted isosurfaces of temperature and density (Fig. 3), marking the strong cyclones $\mathrm{C} 2$ and $\mathrm{C} 4$, while the isolines deepened well below the mean for the line in anticyclonic eddy A4 and A5 at $17^{\circ} \mathrm{W}$. In the shear area between $\mathrm{C} 4$ and $\mathrm{A} 5$ at $17.5^{\circ} \mathrm{W}$, a deep chlorophyll maximum (DCM) was observed, with values of around $0.4 \mathrm{mg} \mathrm{m}^{-3}$ at $50 \mathrm{~m}$ depth, while the presence of $\mathrm{F} 2$ and $\mathrm{C} 2$ favoured a DCM above $0.50 \mathrm{mg} \mathrm{m}^{-3}$ at $50 \mathrm{~m}$. The position of DCM in the water column was clearly related to the mesoscale structure, with the shallowest and largest DCM observed at the coldest temperatures at the limits of cyclonic eddies $\mathrm{C} 2$ and $\mathrm{C} 4$.

Starting at station 16, along Line 2 (Fig. 2) the temperature was $19.6^{\circ} \mathrm{C}$ and salinity was 36.9 , lower values than those observed at station $15\left(20^{\circ} \mathrm{C}\right.$ and 37.04 ) at the west wall of our triangle, where A6 was located. These lower values at station 16 showed the effects of filaments originally formed within the Cape Bojador area. Temperature and salinity values showed an even greater reduction, associated with cyclonic 


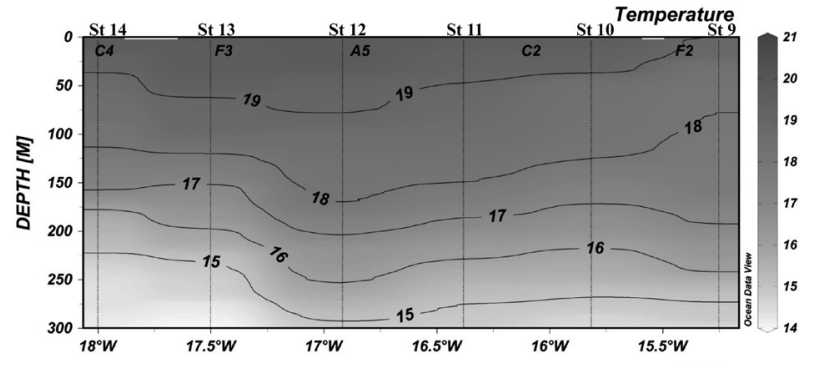

$\mathrm{Chl}$ a
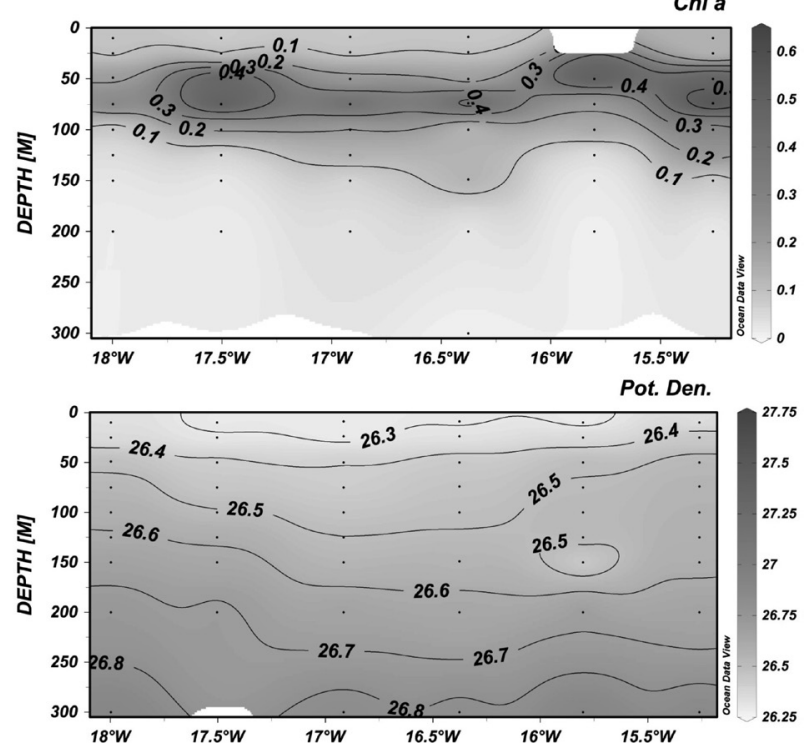

FIG. 3. - Temperature $\left({ }^{\circ} \mathrm{C}\right)$, chlorophyll $a\left(\mathrm{mg} \mathrm{m}^{-3}\right)$ and potential density $\left(\mathrm{kg} \mathrm{m}^{-3}\right)$ vertical profiles in the first $300 \mathrm{~m}(250 \mathrm{~m}$ for Chl a) along line 1 at $27^{\circ} \mathrm{N}$. eddy $\mathrm{C} 5$ and the anticyclonic circulation of the F3-A5 filament-eddy system. After an increase in both SST and SSS related to the presence of A5, the line crossed filament F2 and cyclone $\mathrm{C} 1$, southeast of Gran $\mathrm{Ca}$ naria, with a salinity of 36.59 . At the end of the line, in the channel between Fuerteventura and Cape Juby, the effects of the presence of filament F1 were clearly observed in the presence of the coldest and freshest surface seawater in the area, with a SST of $18.45^{\circ} \mathrm{C}$ and a salinity of 36.54 . Low values were also observed to the west of station 21 up to $14^{\circ} \mathrm{W}$, close to station 22, 60 miles off Cape Juby. Only at station 22, in the wake of Fuerteventura, did the temperature and salinity increase to $18.8^{\circ} \mathrm{C}$ and 36.65 . The effects of the structures observed along this line are also observed in the density anomaly graph (Fig. 4) when cyclones C5 and $\mathrm{C} 1$ cross. The sub-surface structure showed an overall deepening of the isopycnals to the southwest, indicative of the general offshore geostrophic flow. Little or no sign of chlorophyll fluorescence was evident near the surface in either filament. The DCM followed the base of the pycnocline, showing increased chlorophyll fluorescence at the border where the cyclones were located (Fig. 4), with values over $0.45 \mathrm{mg} \mathrm{m}^{-3}$ at $50 \mathrm{~m}$ where $\mathrm{C} 1$ met $\mathrm{F} 2$.

Line 3 along $15^{\circ} \mathrm{W}$ (Fig. 2) had an SST of 18.8 (SSS of 36.77$)$ at the ESTOC site $\left(29.15^{\circ} \mathrm{N}, 15.30^{\circ} \mathrm{W}\right)$, decreasing south of $28^{\circ} \mathrm{N}$ due to the effect of F1 trapped between $\mathrm{C} 1$ and $\mathrm{A} 2$. After briefly crossing the warm and salty area generated by anticyclone A3, the line showed a lower SST and SSS again due to the effect of $\mathrm{F} 2$ at $27^{\circ} \mathrm{N}$.
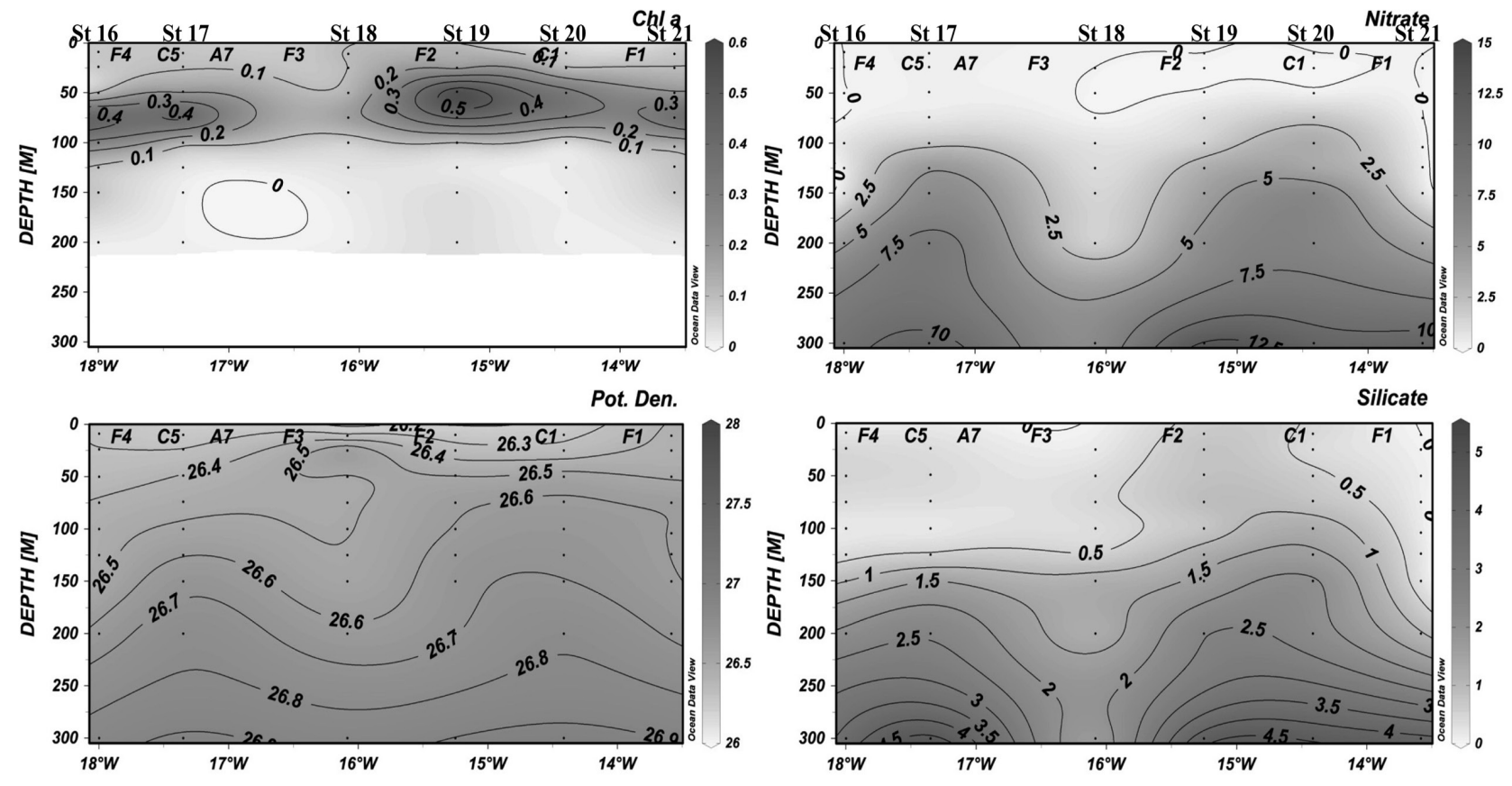

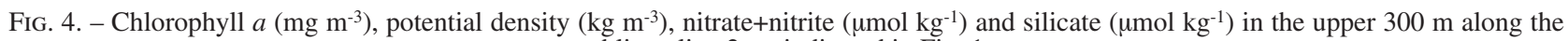
oblique line 2, as indicated in Fig. 1 

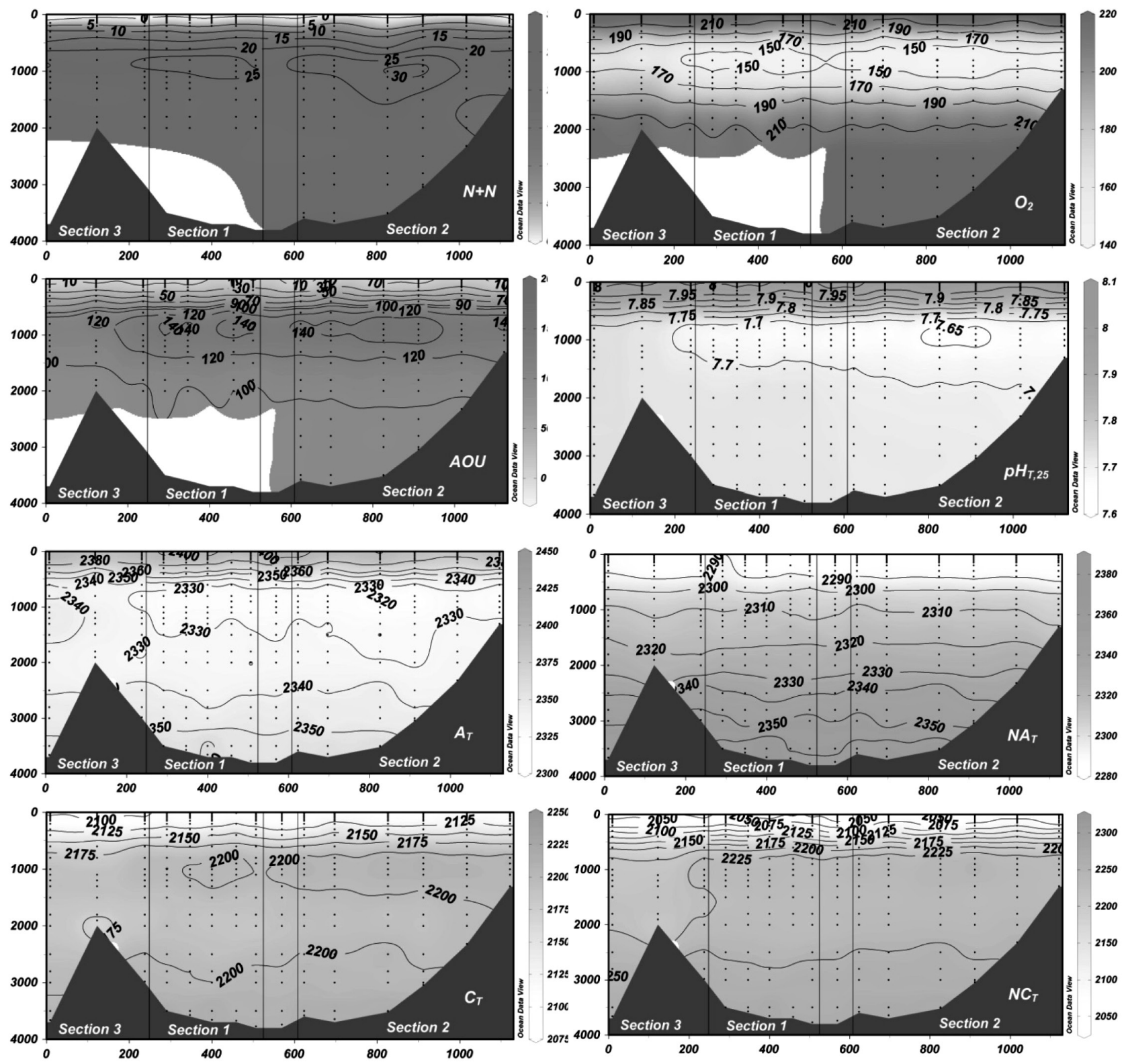

FIG. 5. - Nitrate and nitrite $(\mathrm{N}+\mathrm{N})$, oxygen $\left(\mathrm{O}_{2}\right)$, apparent oxygen utilization $(\mathrm{AOU})$ and carbonate variables, $\mathrm{pH}$ in total scale at $25^{\circ} \mathrm{C}$, total alkalinity $\left(\mathrm{A}_{\mathrm{T}}\right)$, total dissolved inorganic carbon $\left(\mathrm{C}_{\mathrm{T}}\right)$ and normalized to a constant salinity of $35 \mathrm{NA}_{\mathrm{T}}$ and $\mathrm{NC}_{\mathrm{T}}$ from ESTOC station to station 21 following the cruise track. The three lines indicated in Figure 1 are labelled.

The presence of these mesoscale structures also affected the pattern of vertical distributions of nutrients, oxygen and carbonate system parameters in the area (Fig. 4 and 5). Nitrate plus nitrite $(\mathrm{N}+\mathrm{N})$, phosphate (not shown) and silicate were nearly zero at surface but were affected by the presence of cyclonic eddies and filaments and then increased with density along the water column (with a maximum around $1000 \mathrm{~m}$ ). Values of $\mathrm{N}+\mathrm{N}$ at $150 \mathrm{~m}$ depth for the ESTOC station, north of the Canary Islands and outside the field of eddies, were close to $1.25 \mu \mathrm{mol} \mathrm{\textrm {kg } ^ { - 1 }}$. However, at the stations located on the cyclonic eddies C1 (st. 20), C5 (st. 17) and C4 (st. 14) values at $150 \mathrm{~m}$ reached, re-

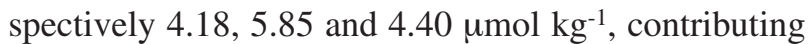
to higher chlorophyll levels in this area. These values were found at around $200 \mathrm{~m}$ for the ESTOC station. The position of the DCM is located at $70 \mathrm{~m}$, in the strong boundary and shearing area between cyclone $\mathrm{C} 4$ and anticyclone A5 (st. 13 and st 14, Fig. 3). However, the presence of the moderate thermocline hinders the manifestation of eddies in the upper $50 \mathrm{~m}$, limiting the effects on the distribution profiles. Phosphate distribution (not shown) is very similar to nitrate distribution, with a high correlation between them $\left(r^{2}=0.99, \mathrm{~N}: \mathrm{P}\right.$ $=16.3 \pm 0.1, \mathrm{~N}=335$ ). In order to study the effect of nutrient input on phytoplankton growth inside the eddy 
field, it is important to determine the ageing status of a given upwelled water mass parcel. Whereas young upwelled water contains nutrients mostly in dissolved inorganic forms, aged upwelled water has had its nutrients transformed into organic forms. We applied the ageing upwelling index $\left(A U I_{C}\right)$ of Takahashi et al. (1993) following the nomenclature of degree of nutrient consumption $\left(\mathrm{DNC}_{C}\right)$ of Chen et al. (2004)

$D N C_{C}=A U I_{C}=0.7 \mathrm{Chl} a /((N+N)+0.7 \mathrm{Chl} a)$

where the constant 0.7 is a conversion factor between chlorophyll $a$ (in $\mathrm{mg} \mathrm{m}^{-3}$ ) and inorganic nitrogen (in umol $\mathrm{l}^{-1}$ ) and is assumed to be similar to that reported in the above two studies. $D N C_{C}$ is nearly zero in newly upwelled water due to the fact that there is an insignificant amount of phytoplankton. If there are large amounts of chlorophyll and low nutrients due to active phytoplankton uptake, $D N C_{C}$ is 1 in the old upwelled water. $D N C_{C}$ was relatively low in the area of eddies (data not shown) with values below 0.45 at stations 10 , 17 and 19 . Only stations 13 and 14 at the position of $\mathrm{C} 4$ showed $D N C_{C}$ values of 0.85 at $75 \mathrm{~m}$, indicating older upwelled water associated with this gyre.

\section{Deep water distribution}

Along the water column (Fig. 5), maximum values and variability are observed as a result of the presence of nutrient-rich AA and nutrient-poor MW. NADW is characterized by a relatively constant $\mathrm{N}+\mathrm{N}$ value of around $20 \mu \mathrm{mol} \mathrm{kg}-1$, a phosphate value of $1.4 \mu \mathrm{mol}$ $\mathrm{kg}^{-1}$ and silicate concentrations increasing rapidly to a maximum value of $25 \mu \mathrm{mol} \mathrm{kg} \mathrm{kg}^{-1}$ at $2000 \mathrm{~m}$ (data not shown). The maximum nutrient values at around 1000 m were not so evident at ESTOC and station 7, indicating very low if any AA contribution.

Figure 5 shows the distribution of the carbonate system variables, $\mathrm{A}_{\mathrm{T}}, \mathrm{pH}_{\mathrm{T}}$ and $\mathrm{C}_{\mathrm{T}}$, over the selected lines. Using data from the surface to $400 \mathrm{~m}$, total alkalinity was clearly related to salinity in this area: $\mathrm{A}_{\mathrm{T}}=$ $146( \pm 19)+61.31( \pm 0.52) \cdot \mathrm{S}\left(r^{2}=0.989, \mathrm{~N}=162\right) \mathrm{STD}$ $=2.39 \mu \mathrm{mol} \mathrm{kg} \mathrm{kg}^{-1}$. After normalization to a constant salinity of 35, $\mathrm{NA}_{\mathrm{T}}$ showed a constant value of 2286 $\pm 3 \mu \mathrm{mol} \mathrm{kg}{ }^{-1}$ down through the first $200 \mathrm{~m}$. A steeper vertical gradient of $\mathrm{NA}_{\mathrm{T}}$ in all lines was observed below the main thermocline. The correlation between $\mathrm{NA}_{\mathrm{T}}$ and silicate distribution was as high as $r^{2}=0.95$ with $\mathrm{n}=362$ and an $\mathrm{NA}_{\mathrm{T}} / \mathrm{SiO}_{2}$ ratio of $1.77 \pm 0.03$, a slope that also depends on the mixing of water masses with contrasting preformed levels of alkalinity and silica. The similar rate of dissolution of hard biogenic structures - both calcium carbonate and opal affect the alkalinity and silicate distribution, respectively-may account for the observed relationship. The ENACW showed a gradient in $\mathrm{NC}_{\mathrm{T}}$, nutrient and apparent oxygen utilization (AOU), with values increasing from the surface down to $800 \mathrm{~m}$. A maximum was observed in all the nutrients at $900-1000 \mathrm{~m}$ related to the presence of AA characterized by a minimum in salinity $(35.142$ at st. 12) and in oxygen, reaching values of $120 \mu \mathrm{mol}$ $\mathrm{kg}^{-1}$ and an AOU of $160 \mu \mathrm{mol} \mathrm{kg}-1 . \mathrm{pH}_{\mathrm{T}}$ at $25^{\circ} \mathrm{C}$ showed an inverse correlation with $\mathrm{AOU}$, indicating the presence of AA south of the Canary Islands at around 900 $\mathrm{m}$, with values as low as 7.62 at stations 18 and 19 and below 7.66 for all the stations in that region. The $\mathrm{pH}_{\mathrm{T}}$ value at the ESTOC site at $900 \mathrm{~m}$ was 7.73. At deeper levels, the MW signal is discerned by its moderate $\mathrm{AOU}$ values, higher $\mathrm{pH}_{\mathrm{T}}$ values and lower nutrient concentration and $\mathrm{NA}_{\mathrm{T}}$ and $\mathrm{NC}_{\mathrm{T}}$ values. Below these intermediate waters a relatively homogeneous layer of nutrients, $\mathrm{pH}_{\mathrm{T}}$ and AOU reaching $2000 \mathrm{~m}$ is observed. Below $2000 \mathrm{~m}$, NADW is characterized by high nutrients and a low AOU of $100 \mu \mathrm{mol} \mathrm{kg} \mathrm{kg}^{-1}$ and a $\mathrm{pH}_{\mathrm{T}}$ of 7.72, slightly higher at the stations to the north of the Canary Islands. The increase in $\mathrm{NC}_{\mathrm{T}}$ with depth of

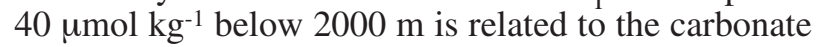
dissolution.

\section{Fugacity and fluxes of $\mathrm{CO}_{2}$ in the area}

Figure 2 presents $f \mathrm{CO}_{2}$ surface seawater and atmospheric values between 14 and 22 March 2000 at $5 \mathrm{~m}$ depth together with SST and SSS. The effect of the mesoscale structure in the area made the surface $f \mathrm{CO}_{2}$ reach higher values for cyclonic eddies. These higher values were, however, associated with lower temperature values related to uplifted seawater. Vertical mixing should bring subsurface $\mathrm{CO}_{2}$-rich waters upwards, since $\mathrm{C}_{\mathrm{T}}$ and $f \mathrm{CO}_{2}$ increases vertically with depth (Fig. $5)$. This carbon dioxide will be reduced by biological activity. In an oligothrophic area such as the Canary Islands only a fraction of this inorganic carbon will be used. Moreover, vertical mixing could bring inorganic carbon into the mixing layer in greater proportions than those established by Redfield, leaving residual carbon that cannot be eliminated by new production.

Seawater $\mathrm{CCO}_{2}$ values along the cruise line were below the atmospheric $f \mathrm{CO}_{2}$ value of $363 \pm 1.2 \mu$ atm. Only between stations 17 and 18, affected by both cyclone C5 and filament F3, were values in seawater similar to those in the atmosphere. Moreover, the area along line 1 and 2 was the most strongly affected by the mesoscale structure for the area. Initially, line 3 along $15^{\circ} \mathrm{W}$ from the ESTOC station to station 9 showed relatively stable values, with $\Delta f \mathrm{CO}_{2}=f \mathrm{CO}_{2, S W}-f \mathrm{CO}_{2, a t m}$ of $-17 \mu$ atm. Only when the ship crossed warm and saltier waters injected by the action of A3, and went inside the effects of filament $\mathrm{F} 2$ around station 9, did the $f \mathrm{CO}_{2, \mathrm{SW}}$ increase by 15 uatm. Along line 1 , the SST increased by about $1{ }^{\circ} \mathrm{C}$ from east to west but was affected by the mesoscale structure, with a strong correlation between SST and $f \mathrm{CO}_{2}$. Along line 2, the highest heterogeneity was observed between stations 17 and 18, where the effects of filaments of the original cell F3 with lower temperature were not correlated with lower $f \mathrm{CO}_{2}$ values. After station 18 and up to station 23 , the high variability observed in the SST and SSS values was 
not correlated with $f \mathrm{CO}_{2}$ values, showing a relatively constant value of $342 \pm 2 \mu$ atm. In order to thoroughly understand this effect, $f \mathrm{CO}_{2}$ values were normalized to the average temperature for the area during this period, $19^{\circ} \mathrm{C}$, as is also depicted in Figure 2. Considering a relatively constant contribution of the $f \mathrm{CO}_{2}$ variability by $\mathrm{CO}_{2}$ atmospheric-oceanic exchange in this area, the observed behaviour must be due to the counterbalance between increased $\mathrm{fCO}_{2}$ waters coming from vertical mixing inside a gyre and from filaments of upwelled waters, and decreased $f \mathrm{CO}_{2}$ waters after primary production favoured by increased nutrient injection by the same two processes. Part of the $\mathrm{CCO}_{2}$ variability in the area was removed after considering solubility effects through temperature correction. Only the area between stations 9 and 10 and the area between stations 17 and 18 kept high $\mathrm{fCO}_{2}$ values. The effect of filament F2 trapped by $\mathrm{C} 1$ and $\mathrm{C} 2$ (Fig. 1) introduced in the area between stations 9 and 10 upwelled waters with higher carbon content that was not removed by primary productivity. The values were $20 \mu$ atm higher than those outside the cyclone area. If we apply the linear relationship observed between $\mathrm{A}_{\mathrm{T}}$ and salinity (see above) for the continuous SSS values together with surface $f \mathrm{CO}_{2}$, the computed $\mathrm{C}_{\mathrm{T}}$ (data not shown) at stations 9 and 10 increased by over $10 \mu \mathrm{mol} \mathrm{kg}{ }^{-1}$, from 2093 $\mu \mathrm{mol} \mathrm{kg}^{-1}$ for the surrounding area to $2104 \mu \mathrm{mol} \mathrm{kg}$ at station 9. Moreover, the $\mathrm{pH}_{\mathrm{T}, 25}$ was reduced in 0.02 units clearly indicating the arriving of subsurface $\mathrm{CO}_{2}$ rich waters. The same behaviour was observed for filament F3 when stations 17 and 18 were crossed, with $f \mathrm{CO}_{2}$ values 15 uatm higher, total inorganic carbon 8 umol $\mathrm{kg}^{-1}$ higher and $0.02 \mathrm{pH}$ units lower than surrounding waters. It can be observed that the area affected by upwelling and filaments generated along the African coast between Cape Juby and Cape Bojador at the end of March (sts. 16-22) showed slightly lower $\mathrm{CCO}_{2}$ values and the lowest inorganic carbon concen-

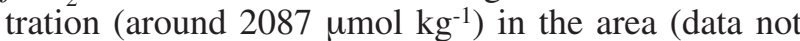
shown), indicating higher inorganic carbon utilization. However, the inorganic carbon introduced in the surface waters due to upwelling was not being removed at all, at least at this time of the year, by the enhanced primary productivity due to the injection of nutrients to the euphotic layer.

The values of $\Delta f \mathrm{CO}_{2}$ between the seawater and the atmosphere were used to estimate $\mathrm{CO}_{2}$ fluxes in the area for the study period (Fig. 2), following the calculation indicated in the experimental section. The whole area acted as a sink of $\mathrm{CO}_{2}$ taking up $9.1 \mathrm{mmol} \mathrm{m}^{-2}$ week $^{-1}$ during the week in which the cruise was carried out. The average wind speed for the week of 14 to 22 March 2000 ranged only from 10 to $15 \mathrm{~km} \mathrm{~h}^{-1}$, a calm period that produced low $\mathrm{CO}_{2}$ fluxes. Values reached $-15 \mathrm{mmol} \mathrm{m}^{-2}$ week ${ }^{-1}$ north of the Canary Islands, related to higher wind speeds, while the values were -10 mmol m${ }^{-2}$ week $^{-1}$ after station 18 , with similar $\Delta f \mathrm{CO}_{2}$ as in the north line but with lower wind speeds. Fluxes of about $-5 \mathrm{mmol} \mathrm{CO}_{2} \mathrm{~m}^{-2}$ were determined along line 1

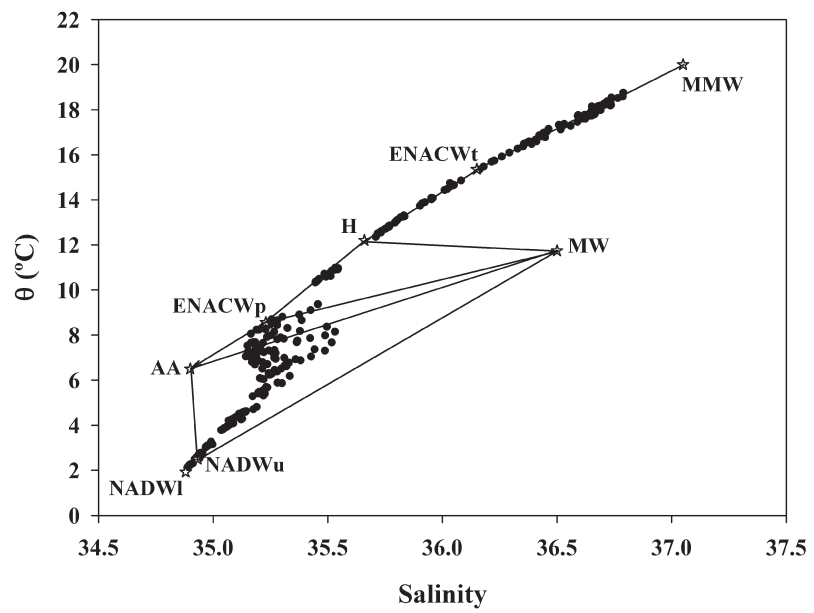

FIG. 6. - $\theta$-S diagram using the bottle data, the thermohaline properties of the different water types indicated as starts and the applied mixing triangles used in the mixing model. Madeira Mode Water (MMW), subpolar East North Atlantic Central Waters (pENACW) and subtropical East North Atlantic Central Waters (tENACW), H end-member, Mediterranean waters (MM), Diluted Antarctic Water (AA) and North Atlantic Deep Water divided into upper and lower limits, uNADW and INADW, were considered. ESTOC data were resolved by replacing the AA point with pENACW.

and were directly controlled by the atmosphere-ocean $\mathrm{CO}_{2}$ gradient. Only close to station 17 , where filament F3 affected the surface distribution, was a zero flux determined. Assuming that the values presented in this study are representative of the area to the south of the Canary Islands of $2^{\circ}$ latitude and $4^{\circ}$ longitude, a total of $0.03 \mathrm{Mt}$ of $\mathrm{CO}_{2}$ were taken up during that week. The value was not extrapolated to a per year data due to the strong seasonal cycle observed for the carbonate system variables in the ocean (González-Dávila et al., 2003; Santana-Casiano et al., 2007).

\section{DISCUSSION}

Figure 6 shows a potential temperature $(\theta)$-salinity diagram for bottle samples collected during the cruise together with the characteristics of the source water types (Table 1). The ENACW were divided into two segments, subpolar (pENACW) and subtropical (tENACW) mode waters. The study area is affected by the formation of Madeira Mode Water (MMW) (Siedler et al., 1987). Consequently, we considered the $\theta-\mathrm{S}$ properties for the tropical ENACW segment as $15.35^{\circ} \mathrm{C}$ and 36.15, (Álvarez et al., 2005). Following Harvey (1982), we chose $12.2^{\circ} \mathrm{C}$ and 35.66 as $\mathrm{H}$ end-member to separate tENACW and pENACW. The pENACW properties were described by Castro et al. (1998), with a potential temperature and salinity of $8.56^{\circ} \mathrm{C}$ and 35.23, respectively (Table 1 ). We also used $\theta$ and salinity values of $\mathrm{NADW}_{\mathrm{u}}$ and $\mathrm{NADW}_{1}$ suggested by Castro et al. (1998) for the upper and lower limits. The termohaline characteristics of MW were selected from Wüst and Defant (1936) (Table 1).

Only station 1 (ESTOC) showed a minimum of salinity and $\mathrm{pH}_{\mathrm{T}}$ at $800 \mathrm{~m}$ (Fig. 5 and 6) of 35.4 and 

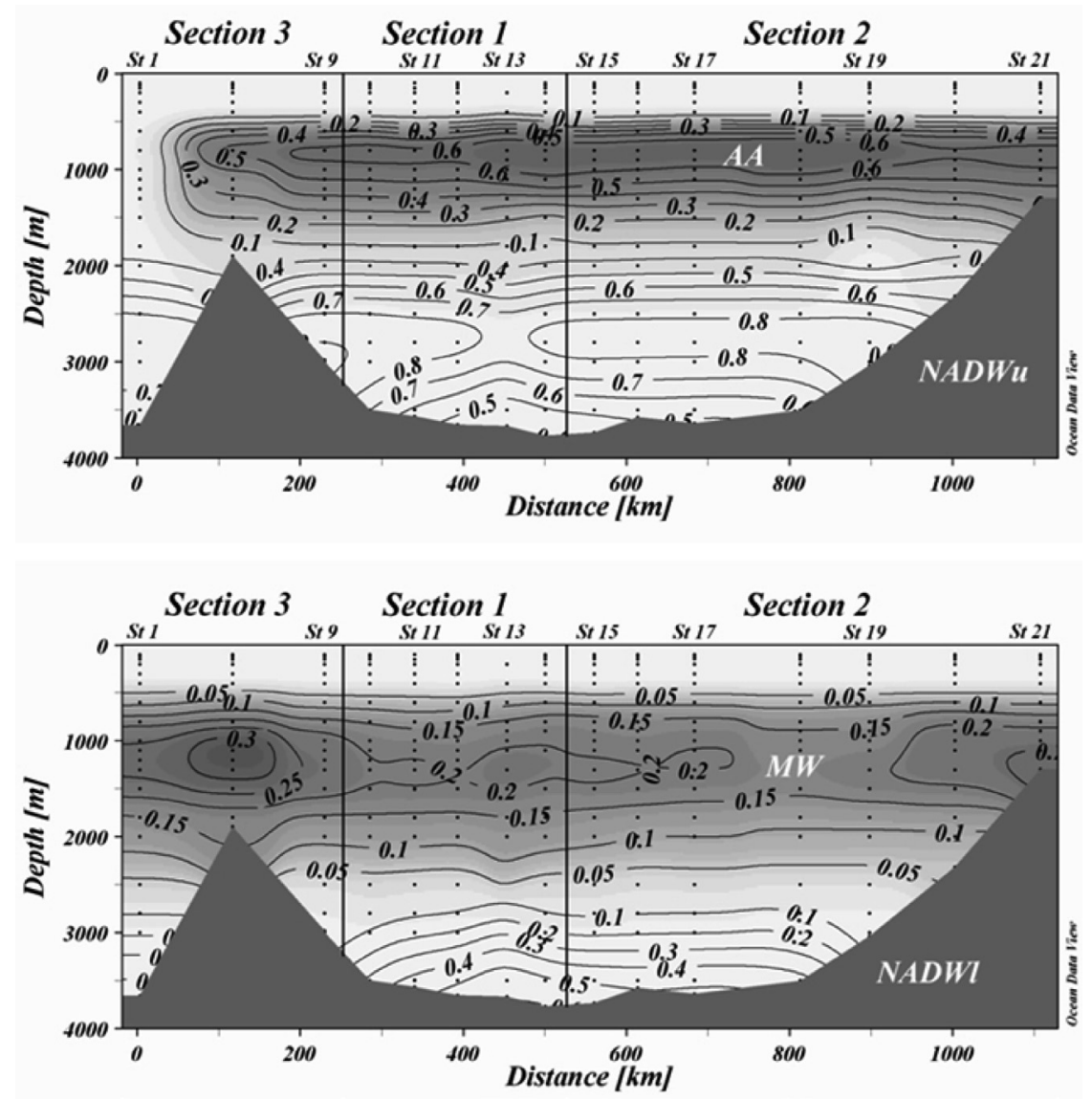

FIG. 7. - Water mass contribution from the ESTOC station to station 21 following the cruise track. Upper panel: Diluted Antarctic Water (AA) and upper North Atlantic Deep Water (uNADW). Lower panel: Mediterranean Water (MW) and lower North Atlantic Deep Water (INADW).

7.72, respectively, indicating the absence of any influence of AA. At this site, the existence of $\mathrm{NACW}_{\mathrm{t}}, \mathrm{H}$, pENACW, MW, NADW ${ }_{\mathrm{u}}$ and $\mathrm{NADW}_{1}$ water masses is well known (Pérez et al., 2001; Alvárez et al., 2005). To the south of the Canary Islands, as stated above, the influence of AAIW was considered. In this study we refer to the diluted-AA (about $11 \%$ of pure AAIW) encountered in the North Atlantic at $20^{\circ} \mathrm{N}$ with the $\theta-\mathrm{S}$ characteristics of $6.5^{\circ} \mathrm{C}$ and 34.9 , in agreement with earlier studies in the area (Fraga et al., 1985; Tsuchiya et al., 1992; Pérez et al., 2001, Alvarez et al., 2005). The contributions of ENACW and NADW waters were computed by the straight equation line from $\mathrm{H}$ tENACW and NADWu-NADWl, respectively. The samples from sea surface to the first $100 \mathrm{~m}$ were excluded from the analysis because their thermohaline properties had been altered by atmospheric conditions.

A sensitivity study of our approach was done for an estimation of error propagation in the chemical variable through the proportion of computed $M_{k, i}$ (presented in Table 1), as indicated in the experimental section. The error in the input variables is smooth transmitted to our chemical parameter determination and presented in Table 1. Moreover, a sensitivity study was also carried out for the presence or absence of water masses and for the structure of the mixing triangles. A particu- lar study was made for the presence of Labrador Sea Water (LSW). Several authors (Käse et al., 1986; McCartney and Talley, 1992, Alvarez et al., 2005) have reported the influence of LSW close to the islands. The LSW reaches the African coast after a long excursion along a cyclonic gyre and mixing with MW (Paillet et al., 1998). In the area considered in this study south of the Canary Islands, the results indicated (data not shown) that the inclusion of this water mass does not improve the mixing model output, and it was therefore not considered.

The estimated error for each chemical variable is within the experimental error and accurately supported the reference $\theta$ and $S$ values used in our calculation. Nitrate, oxygen and $\mathrm{C}_{\mathrm{T}}$ in subsurface waters vary due to the remineralization of organic matter (ROM) and calcium carbonate dissolution. Therefore, they do not completely behave as conservative variables. Thus, we should expect a lower percentage of explained variance for these chemical properties due to these two processes.

In order to determine preformed values for the total inorganic carbon, the $A O U$ was used to correct the $C_{T}$ values for the remineralization of the organic matter

$$
C_{\text {Tbio }}=C_{T}-\left(A O U / R_{C}\right)
$$


where the stoichiometric coefficient $R_{C}$ corresponds to the revisited Redfield ratios estimated by Fraga et al. (1998). The excess carbon in the water column coming from anthropogenic input was computed using the improved TrOCA approach (Touratier et al., 2007), where four known properties are needed $\left(\theta, C_{T}, A_{T}\right.$ and $\left.\mathrm{O}_{2}\right)$.

The distribution of water mass contribution along the stations sampled from the ESTOC site to station 21 using the $\theta$ and $\mathrm{S}$ pairs of data is presented in Table 1 and plotted in Figure 7. The mode of tENACW (not shown) predominated between 200 and $500 \mathrm{~m}$, while the polar mode water was found below the subtropical water at the ESTOC site. The salinity maximum etween 700 and $1500 \mathrm{~m}$ was associated with MW centred at about $1250 \mathrm{~m}$, with a contribution of up to $30 \%$ at the ESTOC station and between Gran Canaria and Fuerteventura, and below $20 \%$ in the southern part. Situated at around the same depth, the AA occupied the region to the south of the Canary Islands from east to west. The AA characteristics used in our study were those observed at $20^{\circ} \mathrm{N}$, where this water dilutes rapidly with ENACW (Reid, 1994), contributing in this area with values of around $70 \%$, characterized by high nutrient, high apparent oxygen utilization and low $\mathrm{pH}$ at the salinity minimum. The highest values of AA contribution were found at $17.5^{\circ} \mathrm{W}$ in line 1 at $27^{\circ} \mathrm{N}$, while relatively constant values of around $70 \%$ were observed along the oblique line, with the highest values at the stations closest to the African slope. The northward spreading of AAIW was claimed to reach $28.5^{\circ} \mathrm{N}$ by Pérez et al., (2001), while Álvarez et al. (2005) placed the limit at the Azores current at $35^{\circ} \mathrm{N}$. Our results showed evidence that the AA flows northward of the Canary Islands along the African coast with a significant signal (Machín and Pelegrí, 2009 and references therein), characterized by a minimum in salinity and a maximum in silicate but, more importantly, by a minimum in $\mathrm{pH}_{\mathrm{T}}$ values of 7.62-7.65 $\mu \mathrm{mol} \mathrm{kg}{ }^{-1}$. North of $28^{\circ} \mathrm{N}$ the mixing among AA with ENACW and MW affected the seawater properties and did not allow us to obtain any signal at the ESTOC site at this time (Santana-Casiano et al., 2007). Only along the African coast were values as high as $70 \%$ for the AA contribution observed at $28^{\circ} \mathrm{N}$ at the northernmost station (St. 21). The uNEADW is centred at $2800 \mathrm{~m}$ over the whole area, with a contribution of $80 \%$, while the INEADW is present below $3000 \mathrm{~m}$, reaching over $40 \%$ at the bottom.

Table 1 presents the nutrient, oxygen and carbonate system end-members which were determined after applying the mixing model. The variances explained by the model are greater than $96 \%$, even considering the low number of samples used to determine the properties of pENACW and NADW. The ratios of variance not explained by the model are $\Delta \mathrm{P}: \Delta \mathrm{N}: \Delta \mathrm{C}: \Delta \mathrm{O}_{2} \equiv 1: 15: 81: 90$ (Table 1), being of the same order as the stoichiometric ratios. $\mathrm{A}_{\mathrm{T}}$ end-members, and particularly $\mathrm{pH}_{\mathrm{T}}$ end-members and residuals, are close to the analytical errors and the model defined its natural variability. $\mathrm{Nu}$ - trient and $\mathrm{pH}_{\mathrm{T}}$ end-members summarized the chemical variability of the water masses. At the upper limit of the subpolar waters, in this area $\mathrm{H}$ showed relatively high values for all the chemical characteristics, and in particular AOU, in comparison with other studies for the Canary region (Pérez et al., 2001, Álvarez et al., 2005). The AA end-member showed the highest AOU values in the intermediate and deep water region because it is the oldest and in its trajectory crosses areas with strong biological activity. The same explanation is applicable to its low $\mathrm{pH}$ and high $\mathrm{C}_{\mathrm{T}}$ and nutrient concentration.

The mixing model removed the variability caused by mixing. The residual variability can be mainly attributed to either ROM or dissolution of hard parts of biogenic matter. Oxygen, $\mathrm{pH}_{\mathrm{T}}$, nitrate and $\mathrm{C}_{\mathrm{T}}$ are the variables most affected by ROM while redissolution increases silicate, $\mathrm{C}_{\mathrm{T}}$ and $\mathrm{A}_{\mathrm{T}}$. The correlation between phosphate and nitrate residuals (data not shown) is $r^{2}=0.38$, with an N:P ratio of $14.7 \pm 0.6$. The AOU and nitrate also showed a significant correlation $\left(r^{2}\right.$ $=0.42$ ), with an $R_{N}$ of $6.2 \pm 0.5$, which is lower than was expected from ROM. The AOU and $\mathrm{C}_{\mathrm{T}}$ residuals showed an $\mathrm{R}_{\mathrm{C}}$ of $1.1 \pm 0.06$, with a correlation of $r^{2}$ $=0.48$, which is also lower than that expected from ROM (Ríos et al., 1998). The high productivity of the upwelling area along line 3, close to the African coast, and the regions located around the permanent features to the south of the Canary Islands contributed to the increase in nutrients in these areas. Furthermore, the diluted AAIW located to the south of the Canary Islands (Fig. 7) also showed a maximum ROM with negative anomalies for $\mathrm{pH}_{\mathrm{T}}$ (over 0.015 ) and positive $\mathrm{C}_{\mathrm{T}}$ (over 9 $\mu \mathrm{mol} \mathrm{kg}{ }^{-1}$ ), AOU (reaching $14 \mu \mathrm{mol} \mathrm{kg}{ }^{-1}$ ) and less important results for nitrate (around $1 \mu \mathrm{mol} \mathrm{\textrm {kg } ^ { - 1 }}$ ) centred at around $900 \mathrm{~m}$ depth (data not presented). The bottom layer was characterized by relatively low ROM.

In order to remove re-mineralization and re-dissolution effects on $\mathrm{C}_{\mathrm{T}}$ end-members, Table 1 also presents the corresponding $\mathrm{C}_{\mathrm{T} \text {,bio }}$ (Eq. 7) end-members. After normalization to a constant salinity of 35 , our values for $\mathrm{C}_{\mathrm{T}, \text { io }}$ end-members showed a good correlation with $\theta\left(r^{2}=0.962\right)$ and agreed with values obtained by other authors in the eastern Atlantic (Table 1). Our value for the AA of $2092 \mu \mathrm{mol} \mathrm{kg}{ }^{-1}$ is in excellent agreement with values for other cruises to the south of the Canary Islands region (Table 2 in Pérez et al., 2001). AAIW in its formation area at the sub-Antarctic Front (SAF) showed values of $\mathrm{C}_{\mathrm{T} \text {,bio }}=2165 \mu \mathrm{mol} \mathrm{\textrm {kg } ^ { - 1 }}$ (Le Groupe CITHER-3, 1998). During its transport, it is mixed with South Atlantic Central Waters and NADWu, which dilute its properties from $100 \%$ at the SAF to $45 \%$ at $24^{\circ} \mathrm{N}$ (Pérez et al., 2001) when linear mixing was assumed between AAIW and pENACW at $40^{\circ} \mathrm{N}\left(9.4^{\circ} \mathrm{C}\right.$,

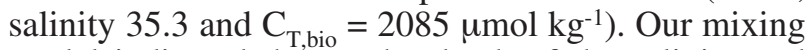
model indicated that at the depth of the salinity and $\mathrm{pH}$ minimum this diluted AA contributed $70 \%$ to the seawater observed to the south of the Canary Islands. That means that the average percentage of pure AAIW 
in the area was only around $5 \%$ compared with $45 \%$ at $24^{\circ} \mathrm{N}$ and the high nutrient and inorganic carbon values for the AA in our area are the result of remineralization along its long northward trajectory and enrichment due to southward transport of high nutrient, $\mathrm{AOU}$ and $\mathrm{C}_{\mathrm{T}}$ upwelled waters off northwest Africa.

Mediterranean waters showed similar $\mathrm{C}_{\mathrm{T} \text {,bio }}$ values (Table 1) to the $2067 \mu \mathrm{mol} \mathrm{kg}{ }^{-1}$ reported by Pérez et al. (2001) and the $2062 \mu \mathrm{mol} \mathrm{kg}{ }^{-1}$ reported by Álvarez et al. (2005), with waters slightly more ventilated during our cruise, as suggested by the oxygen content (201 vs 192). Part of this difference could be compensated by anthropogenic $\mathrm{CO}_{2}$ input and also by the presence of eddies in the area that can inject younger MW in the basin. Both NADW end-members were well related to other values in the literature (Table 1, see also Table 2 in Pérez et al., 2001). Our data for NADWl showed higher (by $5 \%$ ) silicate values than data obtained from the north of the Canary Islands. This may be the result of a deep silica maximum along $24^{\circ} \mathrm{N}$ that increased the values compared with those to the north of the Archipelago, as described by Reid (1994). A similar mixing analysis has been made in other areas of the Eastern North Atlantic Basin by several authors, most of them being summarized in Pérez et al. (2001) and
Álvarez et al. (2005). The end-members showed very good agreement for the different data bases. However, the values for tENACW are not comparable because Madeira Mode Water was included in our study and not considered together with tENACW. The AA endmember observed during this cruise gave higher differences than cruises to the north of the Canary Islands, where the influence of AAIW is smaller.

Anthropogenic carbon $\left(\mathrm{C}_{\mathrm{ANT}}\right)$ penetrated deeper than the depth corresponding to the main thermocline in the Canary Island area, as shown in Figure $8 . \mathrm{C}_{\mathrm{ANT}}$ is expected to accumulate within the subtropical gyres, where Ekman convergence is important. The youngest waters (i.e. those which recently lost contact with the atmosphere) are heavily contaminated by $\mathrm{C}_{\mathrm{ANT}}$. The formation of NADW within Greenland and Norwegian seas and its transport by the Deep Western Boundary Current (DWBC) are responsible for the deep and intense penetration of anthropogenic carbon in large parts of the northern hemisphere. Upper $\mathrm{C}_{\mathrm{ANT}}$ estimations were disregarded due to oxygen oversaturation, as they would lead to an overestimation of $\mathrm{C}_{\mathrm{ANT}}$. The values at $100 \mathrm{~m}$ (average mixed layer depth) were extrapolated to the surface. The waters belonging to NACW are characterized by a
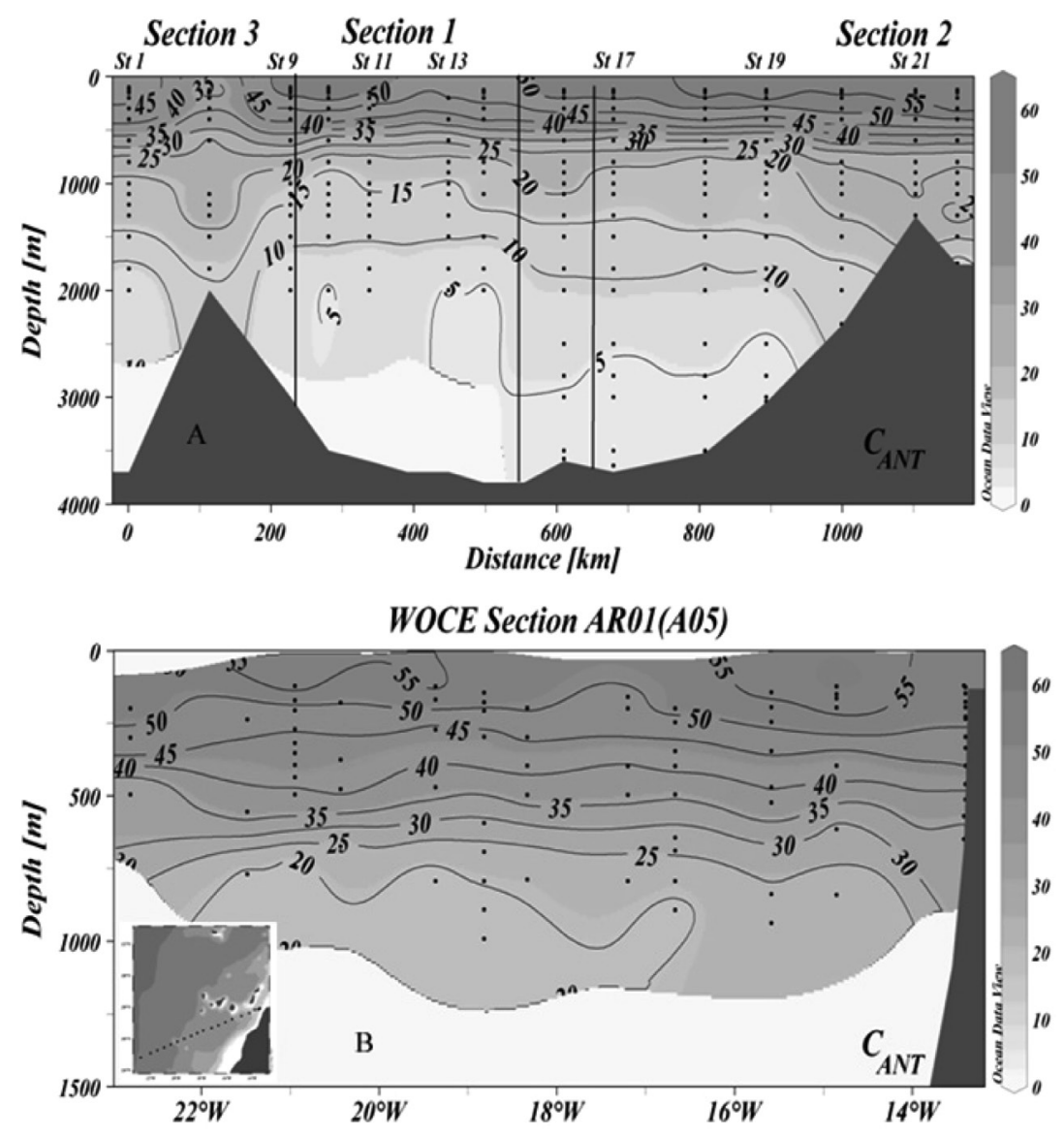

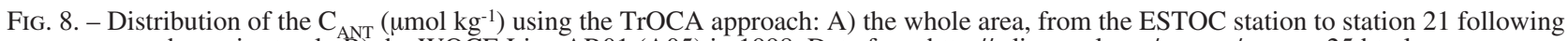
the cruise track, B) the WOCE Line AR01 (A05) in 1998. Data from http://cdiac.ornl.gov/oceans/woce_a25.html 
high concentration of $\mathrm{C}_{\mathrm{ANT}}$, with values of around 60

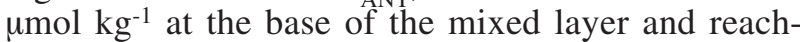
ing $40 \mu \mathrm{mol} \mathrm{kg} \mathrm{kg}^{-1}$ at $500 \mathrm{~m}$. At a depth of around 900 $\mathrm{m}$, the influence of the oldest AAIW can be observed

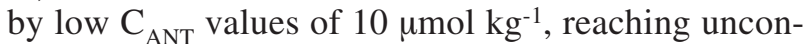
taminated waters below $1500 \mathrm{~m}$. Water located at the ESTOC site with a higher MW influence showed a higher $\mathrm{C}_{\mathrm{ANT}}$ penetration due to its higher content when it is formed in the Gulf of Cadiz.

Line 3 of POS257 was compared with WOCE Line AR01 (A05) (http://cdiac.ornl.gov/oceans/woce_a25. html), carried out in January 1998 (Lee et al., 1998) and focusing on following the interannual variability of $\mathrm{C}_{\mathrm{AnT}}$. The results show (Fig. 8b) the consistence between the two cruises, with values within the uncertainty in the back calculation technique of anthropogenic carbon through the TrOCA method $( \pm 6.25 \mu \mathrm{mol}$ $\mathrm{kg}^{-1}$ ) (Touratier et al., 2007), although an increase in $\mathrm{C}_{\mathrm{ANT}}$ over the years is expected.

\section{CONCLUSIONS}

The biogeochemical distribution to the south of the Canary Islands is strongly influenced by the series of eddies spinning cyclonically and anticyclonically downstream of the islands of the Canary archipelago together with filaments generated in the upwelling cells located at Capes Juby and Bojador, which interact with the eddy field. The aging index of upwelling indicated relatively new upwelled waters in the area. Only stations located to the westernmost points showed the oldest upwelled waters. The $\mathrm{pH}_{\mathrm{T}}$ at $25^{\circ} \mathrm{C}$ appeared as an important water mass indicator for AA with values as low as 7.62 and always below 7.66 for the stations to the south of the Canary Islands. The $\mathrm{pH}_{\mathrm{T}}$ at the ESTOC site at $900 \mathrm{~m}$ was 7.73 .

The application of a simple mixing model for the water masses found to the south of the Canary Islands in March 2000 explained more than $96 \%$ of the chemical variability. The AA end-member showed the highest AOU values in the intermediate and deep water region because it is the oldest and in its trajectory it crosses areas with strong biological activity. The preformed values for the total inorganic carbon showed a good correlation with $\theta\left(r^{2}=0.962\right)$ and agreed with values obtained from other authors in the eastern Atlantic (Table 1). Our $\mathrm{NC}_{\mathrm{T}, \text { bio }}$ value for the AA of 2092 $\mu \mathrm{mol} \mathrm{kg} \mathrm{kg}^{-1}$ confirmed that the northward advection of AA is strongly diluted ( $<5 \%$ of pure AAIW) by MW and pENACW. MW was more ventilated during our cruise, as suggested by the AOU values compared with other values to the north of the Canary Islands with similar $\mathrm{C}_{\mathrm{T} \text {,bio }}$. The upwelling system can also favour the injection of nutrients, $\mathrm{AOU}$ and $\mathrm{C}_{\mathrm{T}}$ to the water masses that advected southward. The $5 \%$ higher silicate values for INADW compared with data obtained north of the Canary Islands may be the result of a deep silica maximum along $24^{\circ} \mathrm{N}$.

\section{ACKNOWLEDGEMENTS}

The authors thank all the participants in the Poseidon 257 cruise, and in particular the officers and crew of the research vessel. Special thanks are also due to the Laboratoire d'Etudes en Gèophysique et Océanographie Spatiale (LEGOS, Tolouse) for providing us with climatological wind and SST data at the ESTOC site and the SeaS Canarias-Departamento de Biología ULPGC-Viceconsejería de Pesca (GAC) for providing us with the SeaWIFS image in Figure 1. We would also like to thank Dr. F. Machín, who helped us with the development of the mixing model program. The article was much improved by the comments of two anonymous reviewers. This work was partially funded by the CARBOOCEAN 2005-2009, CN 511176-GOCE project and the MOMAC project (CTM2008-05914).

\section{REFERENCES}

Álvarez, M., F.F. Pérez, D.R. Shoosmith and H. L. Bryden. - 2005. Unaccounted role of Mediterranean Water in the drawdown of anthropogenic carbon. J. Geophy. Res., 110: 1-18, doi: 10.1029/2004JC002633.

Arístegui, J., P. Sangrá, S. Hernández-León, M. Cantón, A. Hernández-Guerra and J.L. Kerling. - 1994. Island-Induced eddies in the Canary Islands. Deep-Sea Res., 41: 1509-1525.

Arístegui, J., P. Tett, A. Hernández-Guerra, G. Basterretxea, M.F. Montero, K. Wild, P. Sangrá, S. Hernández-León, M. Cantón, J.A. García-Braun, M. Pacheco and E.D. Barton. - 1997. The influence of island-generated eddies on chlorophyll distribution: a study of mesoscale variation around Gran Canaria. DeepSea Res. I, 44: 71-96.

Arístegui, J., E.D. Barton, P. Tett, F.M. Montero, M. Garcia-Muñóz, G. Basterretxea, A. Cussatlegras, A. Ojeda and D. de Armas. 2004. Variability in plankton community structure, metabolism, and vertical carbon fluxes along an upwelling filament (Cape Juby, NW Africa). Prog. Oceanogr., 62 (2-4): 95-113.

Barton, E.D., J. Arístegui, P Tett, M. Cantón, J.G. Braun, S. Hernández-León, L. Nykjaer, C. Almeida, J. Almunia, S. Ballesteros, G. Basterretxea, J. Escánez, L. García-Weill, A. HernándezGuerra, F. López-Laatzen, R. Molina, M.F. Montero, E. Navarro-Pérez, J.M. Rodríguez, K. van Lenning, H. Vélez and K. Wild. - 1998. The transition zone of the Canary Current upwelling region. Prog. Oceanogr., 41: 455-504.

Barton, E.D., G. Basterretxea, P. Flament, E.G. Mitchelson-Jacob, B. Jones, J. Arístegui. and F. Herrera. - 2000. Lee region of Gran Canaria. J. Geophys. Res., 105: 17173-17193.

Barton, E.D. and J. Arístegui. - 2004. The Canary Islands coastal transition zone-upwelling, eddies and filaments. Prog. Oceanogr., 62(2-4): 67-69.

Basterretxea, G., E.D. Barton, P. Pett, P. Sangrá, E. Navarro-Pérez and J. Arístegui. - 2002. Eddy and deep chlorophyll maximum response to wind-shear in the lee of Gran Canaria. Deep-Sea Res., 49: 1087-1101.

Boutin, J. and J. Echeto. - 1995. Estimating the chemical enhancement effect on the air-sea $\mathrm{CO}_{2}$ exchange using the ERS 1 scatterometer wind speeds, in Air-Water Gas Transfer. In: B.J.A.E.C. Monahan (ed.), pp. 827-841, AEON Verlag \& Studio, Hanau, Germany.

Castro, C.G., F.F. Pérez, S.E. Holley and A.F. Ríos. - 1998. Chemical characterisation and modelling of water masses in the northeast Atlantic. Prog. Oceanogr., 41: 249-279.

Chen, C.T.A., L.Y. Hsing, C.L. Liu and S.L. Wang. - 2004. Degree of nutrient consumption of upwelled water in the Taiwan Strait based on dissolved phosphorous or nitrogen. Mar. Chem., 87: 73-86.

Clayton, T.D. and R.H. Byrne. - 1993. Spectrophotometric seawater $\mathrm{pH}$ measurements: Total hydrogen ion concentration scale calibration of m-cresol purple and at-sea results. Deep-Sea Res., 40: 2115-2129. 
Davenport, R., S. Neuer, A. Hernández-Guerra, M.J. Rueda, O. Llinás, G. Fisher and G. Wefer. - 1999. Seasonal and interannual pigment concentration in the Canary Islands region from CZCS data and comparison with observations from the ESTOC time-series station. Int. J. Remote Sens., 20: 1419-1433.

Dickson, A.G. and F.J. Millero. - 1987. A comparison of the equilibrium-constants for the dissociation of carbonic-acid in seawater media. Deep-Sea Res., 34 (10): 1733-1743.

DOE, 1994. In: A.G. Dickson and C. Goyet (eds.), Handbook of Methods for the Analysis of the Various Parameters of the Carbon-Dioxide System in Sea Water, 180 pp., ORNL/CDIAC-74.

Falkowski, P.G., D. Ziemann, Z. Kolber and P.K. Bienfang. - 1991. Role of eddy pumping in enhancing primary production in the ocean. Nature, 282: 677-680.

Fraga, F., E.D. Barton and O. Llinás. - 1985. The concentration of nutrient salts in "pure" North and South Atlantic Central Waters, In: Simposio Internacional Sobre las Area de Afloramiento más Importantes del Oeste Africano, Vol. 1, pp. 25-36, Instituto de Investigaciones Pesqueras, Barcelona, Spain.

Fraga, F., A.F. Ríos, F.F. Pérez and F.G. Figueiras. - 1998. Theoretical limits of oxygen:carbon and oxygen:nitrogen ratios during photosynthesis and mineralisation of organic matter in the sea. Sci. Mar., 62(1-2): 161-168.

González-Dávila, M., J.M. Santana-Casiano, M. Rueda and O. Llinás. - 2003. Seasonal and interannual variability of sea surface carbon dioxide species at the European Station for Time Series in the Ocean at the Canary Islands (ESTOC) between 1996 and 2000, Global Biogeochem. Cycles, 17 (3): 1076.

González-Dávila, M., J.M. Santana-Casiano, D. de Armas and M. Suarez-Tangil. - 2006. The influence of island generated eddies on the carbon dioxide system, south of the Canary Islands. Mar. Chem., 99: 177-190.

González-Dávila, M., Santana-Casiano, J.M. and E.F. GonzálezDávila. - 2007. Interannual variability of the upper ocean carbon cycle in the northeast Atlantic Ocean. Geophys. Res. Lett., 34(7): L07608.

Hammersley, J.M. and D.C. Handscomb. - 1964. Monte Carlo Methods. John Wiley \& Sons, New York, 177 pp.

Hansen, H.P. and K. Grasshoff. - 1983. Automated chemical analysis. In: Methods of Seawater Analysis, pp. 368-376. Verlag Chemie, Weinheim.

Harvey, J. - 1982. $\theta-\mathrm{S}$ relationship and water masses in the eastern North Atlantic. Deep-Sea Res., 29(8A): 1021-1033.

Käse, R. H., J.F. Prince, P.L. Richardson and W. Zenk. - 1986. A quasi-synoptic survey on the thermocline circulation and water masses distribution within the Canary Basin. J. Geophys. Res., 91: 9739-9748.

Le Groupe CITHER-3. - 1998. Recueil de données. Volume 3: Traceurs Géochimiques. 586 pp. Rapport Interne LPO (98-03)

Lee, K., R. Wanninkhof and R. Feely. - 1998. Carbon Dioxide, Hydrographic, and Chemical Data Obtained During the R/V Ronald Brown in the Atlantic Ocean During WOCE Line AR01 (A05) (23 Jan. - 24 Feb., 1998).

Longhurst, A. - 1998. Ecological Geography of the Sea. Academic Press, San Diego and London.

Machín, F. and J.L. Pelegrí. - 2009. Northward penetration of Antarctic intermediate water off northwest Africa. J. Phys. Oceanogr., 39: 512-535.

McCartney, M. and T. Talley. - 1982. The subpolar mode water of the North Atlantic Ocean. J. Phys. Oceanogr., 12: 1169-1188.

McGillicuddy, Jr., D.J., Anderson, L.A., Doney, S.C. and M.E. Maltrud. - 2003. Eddy-driven sources and sinks of nutrients in the upper ocean: results from 0.1 degree resolution model of the North Atlantic. Global Biogeochem. Cycles, 17(2): 1035, doi:10.1029/2002GB001987.

Mehrbach, C., C.H. Culberso, J.E. Hawley and R.M. Pytkowic. - 1973. Measurements of apparent dissociation-constants of carbonic-acid in seawater at atmospheric-pressure. Limnol. Oceanogr., 18(6): 897-907.

Mintrop, L., F.F. Perez, M. Gonzalez-Davila, J.M. Santana-Casiano and A. Körtzinger. - 2000. Alkalinity determination by potentiometry: Intercalibration using three different methods. Cienc. Mar., 26(1): 23-37.
Paillet, J., M. Arhan and M.S. McCartney. - 1998. Spreading of Labrador Sea Water in the eastern North Atlantic. J. Geophys. Res., 103(C5): 10223-10239.

Pérez, F.F., A.F. Ríos, C.G. Castro and F. Fraga. - 1998. Mixing analysis of nutrients, oxygen and dissolved inorganic carbon in the upper and middle North Atlantic ocean east of the Azores. $J$. Mar. Syst., 16(3-4): 219-233.

Pérez, F.F., L. Mintrop, O. Linás, M. González-Dávila, C.G. Castro, M. Álvarez, A. Körtzinger, J.M. Santana-Casiano, M.J. Rueda and A.F. Ríos. - 2001. Mixing analysis of nutrients, oxygen and inorganic carbon in the Canary Islands region. J. Mar. Syst., 28: 183-201.

Pollard, R.T., M.J. Griffiths, S. Cunningham, J.F. Read, F.F. Pérez and A.F. Ríos. - 1996. Vivaldi 1991 - A study of the formation, circulation and ventilation of Eastern North Atlantic Central Water. Prog. Oceanogr., 37: 167-192.

Reid, J.L. - 1994. On the total geostrophic circulation of the North Atlantic Ocean: Flow patterns, tracers and transports. Prog. Oceanogr., 33: 1-92.

Reynolds, R.W. and T.M. Smith. - 1994. Improved global sea surface temperature analyses using optimum interpolation. $J$. Clim., 7: 929-948.

Ríos, A.F., F.F. Pérez and F. Fraga. - 1992. Water masses in the upper and middle North Atlantic Ocean east of the Azores. Deep-Sea Res. Part A, 39: 645-658.

Ríos, A.F., F. Fraga, F.G. Figueiras and F.F. Pérez. - 1998. A modeling approach to the Redfield ratio deviations in the ocean. Sci. Mar., 62(1-2):169-176.

Santana-Casiano J.M., M. González-Dávila, L.M. Laglera-Baquer and M.J. Rodríguez-Somoza. - 2001. Carbon dioxide system in the Canary region during October 1995. Sci. Mar., 65: 41-49.

Santana-Casiano J.M., M. González-Dávila, M.J. Rueda, O. Llinás and E. González-Dávila. - 2007. The interannual variability of the oceanic $\mathrm{CO}_{2}$ parameters in the northeast Atlantic subtropical gyre at the ESTOC site. Global Biogeochem. Cycles, 21(1), Art. $\mathrm{N}^{\circ}$ GB1015.

Siedler, G., A. Kuhl and W. Zenk. - 1987. The Madeira Mode Water. J. Phys. Oceanogr., 17: 1561-1970.

Speer, K.G. - 1993. The deep silica tongue in the North Atlantic. Deep-Sea Res., 40: 925-936.

Takahashi, T., J. Olafsson, J.G. Goddard, D.W. Chipman and S.C. Sutherland. - 1993. Seasonal variation of $\mathrm{CO}_{2}$ and nutrient in the high latitude surface oceans: a comparative study. Global Biogeochem. Cycles, 7: 843-878.

Tomczak, M. - 1981. An analysis of mixing in the frontal zone of South and North Atlantic central water off northwest Africa. Prog. Oceanogr.. 10: 172-192.

Touratier, F., L. Azouzi and C. Goyet. -2007 . CFC-11, $\Delta^{14} \mathrm{C}$ and ${ }^{3} \mathrm{H}$ tracers as a means to assess anthropogenic $\mathrm{CO}_{2}$ concentrations in the ocean. Tellus B, 59: 318-325.

Tsuchiya, M., L.D. Talley and M.S. McCartney. - 1992. An eastern Atlantic section from Iceland southward across the equator. Deep-Sea Res., 39: 1885-1917.

Wanninkhof, R. - 1992. Relationship between wind-speed and gasexchange over the Ocean. J. Geophys. Res., 97 (C5), 7373-7382.

Wanninkhof, R. and K. Thoning. - 1993. Measurement of fugacity of $\mathrm{CO}_{2}$ in surface-water using continuous and discrete sampling methods. Mar. Chem., 44(2-4): 189-204.

Welschmeyer, N.A. - 1994. Fluorometric analysis of chlorophyll $a$ in presence of chlorophyll $b$ and phaeopigments. Limnol. Oceanogr., 39: 1985-1992.

WOCE. 1994. WOCE Operations Manual, Section 3.1. WOCE Hydrographic Programme, World Ocean Circulation Experiment.

Wright, R.W. and L.V. Worthington. - 1970. The water masses of the North Atlantic Ocean: a volumetric census of temperature and salinity. American Geophysical Society, Series Atlas of the Marine Environment, Vol. 19.

Wüst, G. and A. Defant. - 1936. Atlas of the stratification and circulation of the Atlantic Ocean. Sci. Res. German Atlantic exp. R.V. Meteor, 1925-1927, Vol. 6.

Received November 1, 2008. Accepted July 30, 2010.

Published online November 13, 2010. 